\title{
Article
}

\section{Healthy Workplaces: Plantscaping for indoor environmental quality}

Smith, Andrew James and Pitt, Michael

Available at http://clok.uclan.ac.uk/1629/

Smith, Andrew James and Pitt, Michael (2011) Healthy Workplaces:

Plantscaping for indoor environmental quality. Facilities, 29 (3/4). pp. 169-

187. ISSN 0263-2772

It is advisable to refer to the publisher's version if you intend to cite from the work.

http://dx.doi.org/10.1108/02632771111109289

For more information about UCLan's research in this area go to

http://www.uclan.ac.uk/researchgroups/ and search for <name of research Group>.

For information about Research generally at UCLan please go to

http://www.uclan.ac.uk/research/

All outputs in CLoK are protected by Intellectual Property Rights law, including Copyright law. Copyright, IPR and Moral Rights for the works on this site are retained by the individual authors and/or other copyright owners. Terms and conditions for use of this material are defined in the policies page.

\section{CLoK}

Central Lancashire online Knowledge www.clok.uclan.ac.uk

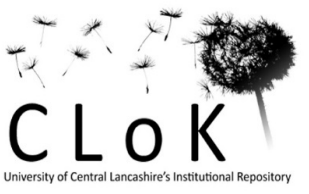


Smith, Andrew James and Pitt, Michael (2011) Healthy Workplaces: Plantscaping for indoor environmental quality. Facilities, 29 (3/4). ISSN 02632772

This is the Author's Pre-Print of the accepted article. It is available at http://clok.uclan.ac.uk/1629

This work was first published in Facilities http://www.emeraldinsight.com/journals.htm?issn=0263-2772

This document is made available via the University of Central Lancashire's Research Repository according to the publishers Open Access Archive policies which are available from

http://www.emeraldinsight.com/about/policies/copyright.htm

Please scroll down to view the document. Refer to the repository record for this item and our policy information available from the repository home page. 


\section{Abstract}

\section{Purpose}

The purpose of this paper is to investigate the indoor environmental quality benefits of plants in offices by undertaking trials using live plants.

\section{Methodology/Approach}

Using two offices in the same building, one with plants and one as a control, daily tests were undertaken for relative humidity, carbon dioxide, carbon monoxide and volatile organic compounds (VOCs). Results were analysed to identify any differences between the office with plants and the one without.

\section{Findings}

Relative humidity increased following the introduction of plants and more significantly following additional hydroculture plants being installed, taking it to within the recommended range. Carbon dioxide was slightly higher in the planted office for the majority of the trial although there was an overall reduction in both offices. Carbon monoxide levels reduced with the introduction of plants and again with the additional plants. VOC levels were consistently lower in the non-planted office.

\section{Research Limitations}

It would be useful to extend this research in a greater range of buildings and with more flexible VOC monitoring equipment.

\section{Practical Implications}

This paper suggests that plants may provide an effective method of regulating the indoor environmental conditions within buildings. This can potentially lead to performance gains for the organisation and a reduction in instances of ill-health among the workforce.

\section{Originality/Value}

The majority of previous studies have relied on laboratory work and experimental chambers. This research aims to apply previous findings to a real working environment to determine whether the air purifying abilities of plants have practical relevance in the workplace.

Key Words: plants, health, productivity, IAQ, humidity, VOCs

Article Type: Research Paper

\section{Introduction}

Research linking engagement to job performance has now begun to emerge and, while further research is required, the published studies suggest a positive correlation 
between engagement and performance. Engagement can be described as a positive, fulfilling state of work related wellbeing (Bakker et al., 2008).

It has been suggested (Pech and Slade, 2006) that work engagement is decreasing within organisations and disengagement is on the increase. Studies have shown that job resources are positively associated with work engagement and these include physical, social or organisational aspects of the job that may reduce job demands, assist achievement of work goals or stimulate personal growth, learning and development (Bakker et al., 2008). Smith and Pitt (2009) suggest that the workplace could be considered a job resource, which either positively or negatively impacts upon engagement.

Literature on the relationship between engagement and work performance is relatively scarce but it appears that engaged workers tend to perform better than non-engaged workers because they experience positive emotions, better health, they create their own job and personal resources and transfer their engagement to others (Bakker et al., 2008).

Therefore, if the workplace is an intrinsic job factor and constitutes a resource, which would be positively associated with work engagement, as one of many contributory resources, a high quality working environment seems likely to contribute to an engaged, and hence, productive workforce. In the same way, a poor quality working environment is likely to be a detracting factor from an engaged workforce.

Several studies have attempted to link environmental factors about the workplace to performance or productivity and it has been suggested that office productivity could be improved by $4-10 \%$ by improving the indoor environmental conditions (ClementsCroome and Baizhan, 2000).

Roelofsen (2002) questions the effect of the level of comfort on the productivity of people working in office environments and attempts to quantify this relationship as an aid to strategic decision making regarding the work environment within the facilities management process and puts particular emphasis on thermal conditions. He argues that the adverse effect of the building environment on the performance of each individual does not have to be substantial to result in a relatively high loss of productivity for the organisation as a whole.

A pilot research project among 170 people in six office buildings found a clear relationship between job stress, job dissatisfaction and the indoor environment and following improvements to the indoor environment, a productivity increase of $10 \%$ was noted (Roelofsen, 2002).

This paper examines the role of indoor environmental quality in contributing to productivity and details the findings of a research trial of indoor plants in an office building. The results of the trial suggest that indoor environmental conditions may be improved, hence improving productivity by introducing plants into the office.

\section{Indoor environmental quality and productivity}


Roelofsen (2002) highlights that the two most significant factors influencing productivity are the thermal environment and air quality but that the way in which people experience air quality is dependent on the thermal environment. Leaman (1995) concurs, stating that people who are unhappy with temperature and air quality are more likely to say this affects their productivity at work. Additionally, he adds lighting and noise conditions to this list. Wood (2003) also states that improving indoor air quality is among the most profitable investments building managers can make as even small improvements in IAQ will directly improve productivity. Further, he outlines that among workplace performance criteria, the environmental factor, amenity, i.e. level of comfort afforded by natural daylight, views, air quality, cooling, heating, lighting and catering facilities is ranked 5 in a scale of one to five in importance in surveys conducted in offices worldwide.

Wood (2003) also states that reduced productivity is difficult to quantify but various studies have been carried out, measuring various performance factors and it has been shown that productivity declines sharply as building-related health complaints rise, with the average productivity loss in most of these studies being $12 \%$.

The outcomes of a study (Leaman, 1995) in which respondents were surveyed on questions in eight standard groups (environmental conditions, health symptoms, satisfaction with amenities, time spent in building, time spent at task, productivity, perceived control, background data) showed that dissatisfaction is greatest with air quality, which was also associated with the highest reported productivity loss.

In their survey of managers, Crouch and Nimran (1989) studied performance facilitating and inhibiting factors in the work environment and found that some factors of the office environment are more prominent than others as facilitators. Supportive social interaction accounted for $41 \%$ of facilitator responses, followed by physical conditions and ambient environment at 21\%, utilities $10 \%$, information and communication $18 \%$ and workplace experience $11 \%$. They also found that the effects of physical and ambient conditions, utilities and information and communication are symmetrical in that they are perceived to facilitate performance when they are favourable and inhibit performance when they are unfavourable and, while less prominent individually, when combined they account for $40-50 \%$ of all responses about environmental features influencing performance, suggesting that they are important considerations.

Another factor that appears to be closely related to productivity is employee satisfaction. It is often assumed that employees who are more satisfied with the physical environment are more likely to produce better work outcomes (Lee, 2006) and this is therefore, an important key performance indicator for organisations. Given that workplace satisfaction is associated with job satisfaction (Sundstrom et al., 1994; Wells, 2000; Leather et al., 2003) this appears to be a reasonable assumption.

The study by Lee (2006) found that in general, the results supported the belief that satisfaction with the physical environment leads to job satisfaction and that there were large discrepancies between employees' perceptions of their current status and their expectations regarding workplace control, flexibility and workplace adequacy aspects. 
Complaints about indoor air quality tend to come under two headings of discomfort and illness (Rooley, 1997). Building related illnesses include legionnaire's disease, Pontiac fever, humidifier fever, hypersensitivity pneumonitis, occupational asthma and allergic rhinitis (Williams, 1998). Many complaints relate to temperature, dry atmosphere, lack of fresh air and tiredness and although these may be widespread, they are not regarded as illness (Rooley, 1997). These symptoms may be attributable, in many cases, to Sick Building Syndrome (SBS).

Some symptoms of SBS are considered to be in the illness category according to the World Health Organisation's June 1982 Report (Rooley, 1997) and these include eye, nose and throat irritation; dry skin; dry mucous membranes; erythema (skin rash); mental fatigue; headaches; high frequency of airway infections and cough; hoarseness and wheezing; hyper-sensitivity; nausea and dizziness.

Modern construction methods have seen a move towards cheaper, lower maintenance and more durable building materials to replace traditional products such as stone and wood. Modern industry has responded to the market opportunity and contemporary buildings are now constructed with and contain more manufactured rather than natural substances, many being petrochemical based. Wood is replaced by UPVC for windows, synthetic materials replace wool in carpets and plastic replaces wooden furniture and fittings. The market cost of these products does not reflect their real cost in terms of externality effects such as environmental impact and their effects on health (Smith et al., 1998). Additionally, in modern air-conditioned buildings at maximum heating and cooling load periods, more air is recycled within the building than exchanged with outside, a factor that may give rise to sick building syndrome (Costa and James, 1995).

Volatile Organic Compounds (VOCs) are present in buildings, particularly in new or recently refurbished buildings. They are typically associated with materials derived from petroleum products and arise in off-gassing from a variety of building products, furnishings, cleaning products (Williams, 1998), paints, adhesives, carpeting, upholstery, panelling, plastic, vinyl, copying machines, computers and hundreds of other office products (Wolverton and Wolverton, 1993). He et al., (2007) found VOCs to be emitted in varying amounts by the lubricating oil in mechanical parts of office printers. These include substances such as Benzene and Formaldehyde, which in low concentrations can cause skin irritation and dry throats but, in higher concentrations, are linked to cancer.

According to Smith et al., (1998), research in the United States discovered almost three hundred VOC compounds in a single building and over nine hundred in total. The commonest VOCs are formaldehyde, organochlorines and phenols and it is now apparent that these are harmful to health and cause irritation to the skin, eyes, nose and throat, breathing difficulties, headaches, nosebleeds and nausea, and some are carcinogens. Additionally, buildings can still contain products related to the burning of fossil fuels such as carbon monoxide, nitrogen dioxide, sulphur dioxide and carbon dioxide (Smith et al., 1998).

Guo et al., (2004) carried out a study of indoor environments in Hong Kong to risk assess exposures to individual VOCs in different environments, including offices. They found that benzene, styrene, methylene chloride, chloroform, trichloroethylene 
and tetrachloroethylene were the most prevalent VOCs in selected indoor environments.

In the Hong Kong study (Guo et al., 2004), benzene was found to account for approximately $40 \%$ of the lifetime cancer risk associated with each category of indoor environment. Benzene is a natural component of crude oil (Karakitsios et al., 2007) and is found in a range of office products. It is present in many basic items including gasoline, inks, oils, paints, plastics and rubber and is used in the manufacture of detergents, explosives, pharmaceuticals and dyes (Wolverton et al., 1989).

Organochlorines are found in air fresheners, polishes and plastics such as UPVC. Health effects include eye, skin and lung irritation, headaches, nausea, damage to central nervous system, depression and they are also carcinogenic and may cause damage to the liver and kidneys (Smith et al., 1998). Styrene also accounts for a large proportion of lifetime cancer risk in offices (Guo et al., 2004).

Phenols are found in disinfectants, resins, plastics, paints, varnishes and preservatives. They are corrosive to the skin and can cause damage to the respiratory system (Smith et al., 1998).

Williams (1998) points out that building occupants may be exposed to many pollutants simultaneously and although exposure to individual contaminants may be extremely low, the combined effects over time may be much more significant.

However, sick building syndrome is not caused by VOCs alone. Other factors include air which is too hot or too dry, biological agents such as carpet mites and pollen, and particulate matter such as dust and cigarette smoke. Symptoms appear to be worse at higher temperatures and there is evidence that buildings with air conditioning are more susceptible than those with natural ventilation (Smith et al., 1998).

Carbon Dioxide is produced by building occupants (Mui, et al., 2008) breathing and talking. According to Franz (1997), fresh air contains about 21\% oxygen and $0.035 \%$ carbon dioxide. However, the oxygen content is reduced to about $17 \%$ in air which has been breathed out, while the carbon dioxide content rises to $4 \%$. The size of the room, the number of persons occupying it and the ventilating conditions play a significant role in the dispersal of CO2 (Raza et al., 1991).

Allergen sensitisation occurs when the body is exposed to an allergen resulting in an altered capacity to react to that substance. Further exposure can lead to immunoreaction such as asthma, rhinitis, alveolitis, dermatitis or eczema (Rooley, 1997). Some allergens found in offices include insect detritus; dust mite excreta and fungal spores (Penicillium, Trichoderma, Mucro, Cladosporium, Stemphylium, Aspergillus alternaria) (Rooley, 1997).

Contaminated air may also result from contamination of fresh air intakes such as emissions from the building itself or other nearby buildings; vehicle exhaust from street traffic, car parks and loading docks; contamination from industry, streets and construction sites; or outdoor contaminants from other sources being transferred to unexpected situations by wind currents (Williams, 1998). 


\section{Indoor air quality benefits provided by plants}

Air quality benefits provided by indoor plants include improving relative humidity and reducing volatile organic compounds (VOCs) as well as removing carbon dioxide from the air and producing oxygen (Smith and Pitt, 2008). The first evidence of the ability of indoor plants to remove indoor air polluting chemicals was demonstrated in the early 1980s.

Much of the research into the effects of indoor plants on air quality was carried out in the United States by Bill Wolverton and his team during research for National Aeronautics and Space Administration (NASA) into space stations and energy efficient buildings on earth. The NASA research focused on the ability of plants to remove pollutants from air and water. NASA researched the issue for over 15 years (Wolverton et al., 1989).

In the final report of the NASA studies, Wolverton et al., (1989) recommend that following the first step of reducing the off-gassing from buildings and furnishings before installation, plants and associated soil microorganisms be used to reduce trace levels of air pollutants inside future space habitats.

Using a modular structure to represent energy-efficient buildings, Wolverton (1988) demonstrated a dramatic reduction in air pollution in one side of the structure containing the plants, while a large number of air pollutants remained in the other side of the structure, which did not contain plants.

Godish and Guindon (1989) took the NASA research a stage further by examining the removal capabilities of plants under dynamic conditions, where formaldehyde is continuously generated and released from sources with varying emission rates, as would be the case in residential environments. Formaldehyde was generated and released within experimental chambers from particle board panels placed within them.

Fully foliated spider plants reduced formaldehyde from initial chamber levels by 29 $50 \%$ but when the plants were progressively defoliated, formaldehyde levels declined further, with the greatest formaldehyde reduction $(52-90 \%)$ occurring when plants were $50-100 \%$ defoliated (Godish and Guindon, 1989). After the plants were removed from the chambers, the formaldehyde levels slowly recovered to preexposure levels.

Wolverton and Wolverton (1993) conducted experiments with over thirty interior plants, using plants in potting soil and potting soil without plants to test their ability to remove formaldehyde, xylene and ammonia from sealed chambers. Similar to the study by Godish and Guindon (1989), interior panelling made of particle board was also used as a continuous out-gassing formaldehyde source during their experiments.

The Boston fern (Nephrolepis exaltata "Bostoniensis") was found to be the most effective in removing formaldehyde with a removal rate of $1,863 \mu \mathrm{g}$ per hour, followed by the pot mum (Chrysanthemum morifolium) at 1,450 $\mu \mathrm{g}$ per hour and the dwarf date palm (Phoenix roebelenii) at 1,385 $\mu \mathrm{g}$ per hour. The dwarf date palm was the most effective at removing xylene with a removal rate of $610 \mu \mathrm{g}$ per hour and the 
lady palm (Rhapis excelsa) was most effective at removing ammonia at 7,356 $\mu$ g per hour (Wolverton and Wolverton, 1993).

Based on the data obtained by Wolverton and Wolverton (1993), the air in a 9.3 square metre office with a 2.4 metre ceiling would contain $3,916 \mu \mathrm{g}$ of formaldehyde and $493 \mu \mathrm{g}$ of xylene. Two Boston ferns would be capable of removing the formaldehyde from the air in this office, with approximately three Janet Craigs (dracaena deremensis) required to remove the same level of formaldehyde. Two Boston ferns or three Janet Craigs would also be required to remove the xylene from that office (Wolverton and Wolverton, 1993). The results also indicated that both leaves and soil microorganisms are involved in removing these chemicals.

Giese et al., (1994) lend support to the idea of room decontamination by plants. In their study, spider plants were put in contact with formaldehyde over a period of 24 hours and the formaldehyde was removed from the atmosphere of the experimental glass chamber by the plants within 5 hours to below the detection limit. They suggest that a single $300 \mathrm{~g}$ spider plant could detoxify a 100 cubic metre room in six hours.

Oyabu et al., (2003) tested the ability of golden pothos (Epipremmum aureum) to remove ammonia, formaldehyde and acetone from indoor air. They found the purification ability to be high for ammonia because it provides nutrition for the plants, although the ability to remove acetone was much lower, with the acetone level remaining nearly unchanged. They also found that the purification ability increased with increasing numbers of pots and that purification takes longer with increasing molecular weight of the chemical (Oyabu et al., 2003).

The ability of indoor plants to remove carbon dioxide has been well documented. During photosynthesis, plants absorb carbon dioxide from the atmosphere through the stomata (tiny openings on the leaves), while the roots absorb moisture from the soil. Chlorophyll and other tissue in the leaves absorb radiant energy from a light source, which is used to split water molecules into oxygen and hydrogen. Hydrogen and carbon dioxide are used by the plant to form sugars, while oxygen, a by-product of photosynthesis is released into the atmosphere (Wolverton, 1996).

In addition to reducing volatile organic compound concentrations and other gases, plants may also be used to regulate the indoor climate. Plants such as Rhapis palms and Marantas, which need regular misting, or plants with high moisture content could benefit offices with low humidity. It was found that plants can increase the relative humidity of a non air-conditioned building by about 5\%, although the density of planting required to achieve this was higher than would normally be provided for a commercial office environment (Costa and James, 1995).

Lohr and Pearson-Mims (1996) found that, during trials of plants impacting on particulate accumulation, relative humidity was higher when plants were present than when they were not.

Plants also have the ability to remove airborne particles such as dust or more harmful particles such as emissions from office printers. Many studies have shown evidence that outdoor vegetation such as trees and shrubs reduce atmospheric dust but indoor plants also display this characteristic. Plants act as natural filters, causing particles to 
be deposited on the vegetative surface through sedimentation, impaction or precipitation (Lohr and Pearson-Mims, 1996). Vegetation with rough surfaces from fine hairs or raised veins for example, is more efficient in reducing airborne particulates than smooth vegetation (Lohr and Pearson-Mims, 1996).

Their results (Lohr and Pearson-Mims, 1996) showed that in a computer lab, particulate matter was lower in the presence of plants than in their absence. It had previously been speculated that plants may be a source of particulate matter (Owen et al., 1992) but these results (Lohr and Pearson-Mims, 1996) showed that plants do not increase particulate matter but actually reduce it. Particulate matter accumulation was also substantially lower in the office space when plants were present than when they were absent, indicating that plants reduce particulates in interior spaces (Lohr and Pearson-Mims, 1996). Lohr and Pearson-Mims (1996) consider that the accumulation of particles on horizontal surfaces can be reduced by as much as $20 \%$ by adding foliage plants.

Fjeld (2004) undertook a study where plants were provided in the offices of an oil company in Norway and found a 25\% reduction in symptoms reported. Instances of fatigue and headache reduced by $30 \%$ and $20 \%$ respectively, hoarseness and dry throat reduced by around 30\%, coughing by around $40 \%$ and dry facial skin reduced by about $25 \%$. However, it is unclear whether these results were due to improvements in air quality made by the plants or psychological factors.

\section{Methodology}

The trial was carried out in the Edinburgh building of a large financial services company, located at Edinburgh Park, an out of town business park. The building was constructed around 15 years ago and the test area comprised two open plan offices on two floors of the building. These offices were selected due to them being of similar size and orientation, occupied by approximately the same number of people, doing similar jobs.

One of these offices was furnished with indoor plants, while the other acted as a control, with no plants. The office with plants is known as East 1 and the control office is known as East 2. There was an open atrium between the two offices.

Live interior plants were provided in East 1 for a period of six months from February to the end of July 2008. These were installed and maintained by a professional indoor landscaping company as previous research has shown that the plants must be in the optimal condition for them to be successful in regulating the indoor climate within buildings (Costa and James, 1995; Franz, 1997).

For approximately the first 3.5 months of the trial period, a minimal level of planting was provided, followed by an increased level of planting for the remainder of the trial period. The initial installation comprised soil-grown plants and the additional plants provided later were hydroculture varieties, where the plants are grown in granules and water is maintained within the plant container. Soil borne pests such as sciarid flies do not affect hydroculture plants. 
The plants used in the trials were selected for their specific air purification abilities as well as other factors, such as ease of maintenance, light requirements, size, shape and general aesthetic qualities.

For the initial period of the trial, the area on East 1 was furnished with two 1.8m Ficus Alii, one $1.6 \mathrm{~m}$ branched Dracaena Compacta, two $1.6 \mathrm{~m}$ Philodendron Scanden, two $1.6 \mathrm{~m}$ Scindapsus Aureum and seven troughs containing screen planting of approximately $80 \mathrm{~cm}$ in height. The screen planting comprised of Dracaena Gold Coast and Calathea Triostar. These represented a minimal level of planting in comparison to the area of the office. These varieties were all soil-grown plants.

For the second phase of the trial, the level of planting was increased relative to the area of the office and the plants used were hydroculture varieties. The plants installed were two $1.05 \mathrm{~m}$ Schefflera Louisiana, one $1.1 \mathrm{~m}$ Schefflera Arboricola, two $1.1 \mathrm{~m}$ Schefflera Gold Capella, two 80cm Spathiphyllum Sensation, and four troughs, each containing three $80 \mathrm{~cm}$ Philodendron Scanden. Additionally, 39 small desk bowls were provided, each containing one $35-50 \mathrm{~cm}$ plant from the following varieties: Calathea Ornata Sanderiana, Calathea Beauty Star, Dracaena Compacta Malaika, Dracaena Lemon Surprise, Ficus Elastica Melany Petit, Ficus Natasja, Peperomia USA, Peperomia Red Margin. These plants were selected specifically for their high transpiration rate, leading to an increased ability to improve indoor relative humidity.

Maintenance of the plants, such as dusting and watering, was carried out on a threeweekly basis.

Air quality was tested using a Graywolf IAQ-410 air quality monitor on a daily basis. The monitor was calibrated by a professional independently accredited ISO 9001:2008 and ISO 17025 laboratory in order to ensure the accuracy of the monitoring equipment. Checks were carried out for humidity, carbon dioxide and carbon monoxide. Readings were taken at twelve separate locations on each floor and a daily mean figure calculated for each floor on each day to mitigate the effects of any erroneous readings due to other factors, for example being closer to a plant or other item that may affect the reading such as a wet jacket or an open window. Care was taken to ensure readings were taken at the same locations on each day. Additional daily checks were completed for total volatile organic compound concentrations, using a professionally calibrated Tongdy VOC monitor.

Figure 1 shows a floor plan of East 1, detailing the locations of the plants and also where the air quality readings were taken. The layout of East 2 is identical to East 1, with the exception that the middle circulation area where several meeting tables are placed in East 1 is an open atrium in East 2. The air quality readings were taken in the same locations in East 2 as in East 1, except that those in the middle area were taken close to the railing around the atrium in East 2, whereas in East 1 they were taken in the middle of the floor.

\section{Indoor air quality prior to the trial}


Periodic air hygiene assessments have been carried out within the premises. A workplace assessment was carried out on $17^{\text {th }}$ December 2007 and a copy of the report was provided for the purposes of this research.

Within the report it was noted that airborne particle levels were satisfactory, as were carbon dioxide, airborne microbes and air temperature. However, relative humidity levels were recorded below 30\%, increasing the risk of health disorders among sensitive individuals, such as asthma and eczema sufferers, where dry nasal membranes and skin tissue reduces the protection afforded against sensitising agents. The recommended range of relative indoor humidity is $40-70 \% \mathrm{RH}$. It was noted in the report that, although change was desirable, there are no humidity controls within the office areas so no recommendations were made.

\section{Results}

The expectation was that the presence of plants would increase the humidity level so that this would be higher in the areas with plants, compared to the control areas without plants. Additionally, it was expected that humidity levels would increase from the level recorded before the plants were installed in the test location.

The humidity levels in each area were similar over the period of the trials as is evident from figure 2, which shows a comparison of the humidity data for each floor for the period of the trial. However, the trend was for the humidity to be slightly higher on East 1, where the plants were located, although this is not significant. It is also likely that the beneficial effects shown on East 1 would have some influence on East 2 as there is an open atrium, which would enable some air to circulate between each floor, for example by a stack effect whereby warm air rises within the building. Although the difference in humidity levels between East 1 and East 2 is not significant, what is significant is the increase in humidity in East 1, following the introduction of the plants.

A detailed analysis of humidity levels in East 1 helps to establish the humidity benefits of plants. Figure 3 shows the daily average humidity and temperature in East 1 from February to August 2008. This is an average of twelve readings taken in each area of East 1 on each day.

This graph shows that, although there are peaks and troughs, a linear increase in humidity levels has occurred since the plants were installed in East 1. This has taken the humidity to within the recommended range of $40-60 \% \mathrm{RH}$. Due to the nature of humidity, peaks and troughs will always exist as a result of the range of factors which affect it, such as weather conditions, windows being opened or closed, the number of occupants in the room, flow of people around the room as well as many other factors. For example, humidity levels will generally be higher if it is raining outside, particularly as occupants of the building are likely to bring in wet clothes and umbrellas. However, the aim of the FM department is to bring the humidity level to generally within the recommended range as far as possible, whereas prior to the research, it was consistently below $40 \% \mathrm{RH}$. 
A further analysis of the data for east 1 is shown in figures 4 and 5 . Figure 4 shows the initial period, where minimal planting was installed and figure 5 shows the latter period, with an increased number of plants. During the initial period, the humidity level was shown to rise slightly but it was still below the recommended minimum level of $40 \%$ RH. During the period with increased numbers of plants, the humidity level rose more steeply to within the recommended range.

The expectation was that the presence of plants would reduce the levels of Carbon Dioxide and Carbon Monoxide so that the levels of these gases in the areas with plants would be lower than those of the areas without plants. It was also expected that carbon dioxide levels recorded prior to the installation of plants would reduce in the trial area.

Figure 6 shows a comparison of carbon dioxide levels for east 1 and east 2 from February to August 2008. The data is very close between the two floors and no significant differences have been identified. Contrary to expectations, the carbon dioxide level appears to be slightly higher in east 1 for the majority of the trial period. However, carbon dioxide gas is heavier than air so it is likely that some of the carbon dioxide generated on east 2 would drop to east 1 due to the open atrium.

As with humidity, a more meaningful result is shown when the data for east 1 is analysed in more detail. Figure 7 shows the daily average figures with minimal plants installed and figure 8 shows the daily average figures with additional plants installed.

This data shows that the carbon dioxide level reduced significantly with the addition of plants on east 1 to a level around half that prior to the installation of the plants, with the exception of an unexplained peak in March, which was consistent across all readings on a single day, before gradually decreasing again. The reasons for this peak are unclear and a similar pattern was noted on East 2 on that day. Discussions with the building management team did not yield any obvious reason for this peak. There was also not a significant further reduction in carbon dioxide on east 1 with the installation of additional plants.

Carbon monoxide, although recorded in very small volumes prior to the start of the trials, was expected to reduce following the installation of the plants. The carbon monoxide levels reduced relatively significantly from the starting point although several peaks and troughs were recorded. The downward trend continued with the addition of more plants in the latter stage of the trials. This data is shown in figure 9.

As plants are known to absorb volatile organic compounds, the expectation was that VOC levels would be lower in the areas with plants compared to the control areas. Additionally, it was expected that VOC levels would reduce in the trial areas compared to the pre-trial levels.

Contrary to this expectation, it was found that VOC levels were consistently lower in the non-planted area. However, this test was limited by the monitoring equipment, which required to be plugged in to a mains socket and it did not fit several of the sockets within the trial building. Therefore, it may be that the locations of some of the tests were closer to an emitter of VOCs than others. 
Figure 10 shows the comparison of data for east 1 and east 2. A further analysis of the data for east 1 does show a significant reduction in VOC levels, as shown in figure 11. The greatest reduction occurred after the installation of additional plants, which suggests that the VOC level reduced as a result of the installation of plants.

\section{Conclusions}

This paper details the results of a period of trials of indoor plants in offices, where indoor air quality was monitored in order to ascertain whether or not the presence of plants had a beneficial effect on air quality.

The expectation based on previous studies, largely in laboratory settings, was that following the installation of plants in certain areas, relative humidity would increase, carbon dioxide and carbon monoxide would reduce and volatile organic compounds (VOCs) would reduce within these areas.

In the trial building, there was a specific problem with dry indoor air prior to the commencement of the trial in that humidity was generally lower than the recommended minimum level. Some staff had been experiencing skin complaints and other ailments, which were attributed to dry indoor air. The results on humidity were close between the experimental and control areas but a more detailed analysis of the results for the experimental area showed that the plants did appear to have a significant influence, particularly after the installation of additional hydroculture plants, and the humidity level moved to within the recommended range. It is also likely that the presence of the plants influenced the air in the control area due to an open atrium. It would be useful to undertake a further study into the respective benefits of hydroculture and soil grown plants.

The results on carbon dioxide did not always follow the expected pattern. There was little difference between the two floors and in fact, the level appeared to be slightly higher on the floor with the plants for the majority of the trial period. However, as noted above, there was an open atrium and as carbon dioxide is heavier than air, it is likely that concentrations would normally be higher in the experimental area because it was the floor below the control area and, therefore, carbon dioxide generated in the control area would be likely to drop to the floor below. A further analysis of data from the experimental group does show a significant reduction of carbon dioxide to around half its starting value prior to the trial. This suggests that the effect of the plants was substantial and influenced the air quality on two floors.Carbon monoxide, although recorded in small volumes, did decrease relatively significantly, beginning with the minimal plants and continuing after the addition of more plants.

The results on VOCs did not entirely follow the expected pattern as levels were found to be consistently lower in the non-planted area. However, further analysis does show reductions in VOCs following the introduction of the plants, indicating that plants reduce VOC levels. The slightly lower levels in the areas without plants are unexplained although this may be due in part to equipment limitations but also to the open atrium. 
Further research into the VOC content of indoor air is required to establish why the planted areas generally had higher VOC levels than the non-planted areas. It is known that plants emit VOCs after wounding but the plants used in the study were maintained in optimal condition throughout the trial. Therefore, this research needs to be extended in several buildings to establish whether this is a general trend and to investigate reasons for it. Another theory that requires investigation is the contribution of the plant containers themselves to VOC emissions. It is inevitable that some VOCs would be emitted by the plant containers in this study but the actual level is unknown. It may be possible to define an optimum plant and container package to minimise VOC emissions.

Overall, these results provide an indication that plants help to balance indoor relative humidity and reduce carbon monoxide and VOC levels. However, further research may be useful across a larger sample of buildings to determine whether this pattern of results can be expected in other buildings, and particularly to establish why the results on carbon dioxide and VOCs were not more favourable.

In practical terms, plants could prove to be a relatively low maintenance method of regulating the indoor environmental quality of workplaces.

\section{References}

Bakker, A.B., Schaufeli, W.B., Leiter, M.P., Taris, T.W. (2008) "Work engagement: An emerging concept in occupational health psychology." Work \& Stress, Vol. 22, No. 3, pp. $187-200$.

Clements-Croome, D., Baizhan,L. (2000) "Productivity and indoor environment." Proceedings of Healthy Buildings 2000, Vol. 1.

Costa, P., James, R.W. (1995) "Constructive use of vegetation in office buildings." Plants for People Symposium, The Hague, Netherlands, 23 November 1995. Available http://www.healthygreenatwork.org/index_en.cfm?act=artikelen.details\&varart=18 [Accessed 30/12/08].

Crouch, A., Nimran, U. (1989) "Perceived facilitators and inhibitors of work performance in an office environment." Environment and Behavior, Vol. 21, No. 2, pp. $206-226$.

Fjeld, T. (2004) “Do plants in offices promote health?” Available from: http://www.healthygreenatwork.org/index_en_cfm?act=artikelen.details\&varart=15 [Accessed: 30/12/2008].

Franz, J. (1997) “The Indoor Plants.” In Menges, A. (ed.) LOG ID BGW Dresden. Opus.

Giese, M., Bauer-Doranth, U., Langebartels, C., Sandermann Jr., H. (1994) "Detoxification of formaldehyde by the spiderplant (Chlorophytum comosum L.) and 
by soybean (Glycine max L.) cell-suspension cultures,” Plant Physiology, Vol. 104, pp. $1301-1309$.

Godish, T., Guindon, C. (1989) "An assessment of botanical air purification as a formaldehyde mitigation measure under dynamic laboratory chamber conditions," Environmental Pollution, Vol. 61, pp. 13 - 20.

Guo, H., Lee, S.C., Chan, L.Y., Li, W.M. (2004) "Risk assessment of exposure to volatile organic compounds in different indoor environments," Environmental Research, Vol. 94, No. 1, pp. 57 - 66.

He, C., Morawska, L., Taplin, L. (2007) "Particle emission characteristics of office printers”, Environmental Science and Technology, Vol. 41, No. 17, pp. 6039 - 6045.

Karakitsios, S.P., Papaloukas, C.L., Kassomenos, P.A., Pilidis, G.A. (2007) "Assessment and prediction of exposure to benzene of filling station employees," Atmospheric Environment, Vol. 41, No. 40, pp. 9555 - 9569.

Leaman, A. (1995) “Dissatisfaction and office productivity.” Facilities, Vol. 13, No. 2, pp. $13-19$.

Leather, P., Beale, D., Sullivan, L. (2003) "Noise, psychosocial stress and their interaction in the workplace.” Journal of Environmental Psychology, Vol. 23, pp. 213 $-222$.

Lee, S.Y. (2006) "Expectations of employees toward the workplace and environmental satisfaction.” Facilities, Vol. 24, No. 9/10, pp. 343 - 353.

Lohr, V.I., Pearson-Mims, C.H. (1996) "Particulate matter accumulation on horizontal surfaces in interiors: Influence of foliage plants.” Atmospheric Environment, Vol. 30, No. 14, pp. 2565 - 2568.

Mui, K.W., Wong, L.T., Hui, P.S. (2008) "Feasibility study on benchmarking indoor air quality (IAQ) of air-conditioned offices in Hong Kong." Healthy and Creative Facilities, Proceedings of the CIB W70 Conference in Facilities Management, Edinburgh, UK, $16^{\text {th }}-18^{\text {th }}$ June 2008, pp. $217-223$.

Owen, M.K., Ensor, D.S., Sparks, L.E. (1992) “Airborne particle sizes and sources found in indoor air.” Atmospheric Environment, Vol. 26A, pp. 2149 - 2162.

Oyabu,T., Sawada, A., Onodera, T., Takenaka, K., Wolverton, B. (2003) "Characteristics of potted plants for removing offensive odors," Sensors and Actuators B, Vol. 89, pp. 131 - 136.

Pech, R., Slade, B. (2006) "Employee disengagement: Is there evidence of a growing problem?” Handbook of Business Strategy, Vol. 7, No. 1, pp. 21 - 25.

Raza, S.H., Shylaja, G., Murthy, M.S.R., Bhagyalakshmi, O. (1991) “The contribution of plants for CO2 removal from indoor air,” Environment International, Vol. 17, pp. $343-347$. 
Roelofsen, P. (2002) "The impact of office environments on employee performance: the design of the workplace as a strategy for productivity enhancement." Journal of Facilities Management, Vol. 1, No. 3, pp. 247 - 264.

Rooley, R. (1997), "Sick Building Syndrome - the real facts: What is known, what can be done,” Facilities, Vol. 15, No. 1/2, pp. 29 - 33.

Smith, A., Pitt, M. (2009) "Sustainable workplaces: Improving staff health and wellbeing using plants.” Journal of Corporate Real Estate, Vol. 11, No. 1, pp. 52 63.

Smith, M., Whitelegg, J., Williams, N (1998) “Greening the Built Environment." Earthscan Publications, London.

Sundstrom, E., Town, J.P., Rice, R.W., Osborn, D.P., Brill, M. (1994) “Office noise, satisfaction and performance,” Environment and Behavior, Vol. 26, No. 2, pp. 195 222.

Wells, M. (2000) "Office clutter or meaningful personal displays: The role of office personalization in employee and organizational well-being." Journal of Environmental Psychology, Vol. 20, No. 3, pp. 239 - 255.

Williams, P. (1998) "Air-conditioned environments: System faults affecting occupant productivity and well-being in Australian buildings,” The Cutting Edge 1998. RICS Research.

Wolverton, B.C. (1988) "Foliage plants for improving indoor air quality." National Aeronautics and Space Administration, Report No. TM-108055. Presented at National Foliage Foundation Interiorscape Seminar, Hollywood, FL, July $19^{\text {th }} 1988$. Available at: http://ntrs.nasa.gov/archive/nasa/casi.ntrs.nasa.gov/19930073015_1993073015.pdf (Accessed 14/01/2008).

Wolverton, B.C., Johnson, A., Bounds, K. (1989b) "Interior landscape plants for indoor air pollution abatement: Final Report. National Aeronautics and Space Administration, Report No. TM-101768. Available at: http://ntrs.nasa.gov/archive/nasa/casi.ntrs.nasa.gov/19930073077_1993073077.pdf (Accessed 14/01/2008).

Wolverton, B.C., Wolverton, J.D. (1993) "Plants and soil microorganisms: Removal of formaldehyde, xylene and ammonia from the indoor environment," Journal of the Mississippi Academy of Sciences, Vol. 38, No. 2, pp. 11 - 15.

Wolverton, B.C. (1996) How to grow fresh air: 50 houseplants that purify your home or office. Weidenfeld and Nicolson, London.

Wood, R.A. (2003) "Improving the indoor environment for health, well-being and productivity." Proceedings of Greening Cities: a new urban ecology, Sydney, Australia, $30^{\text {th }}$ April. 
Figure 1: Floor plan of East 1 showing locations of plants and air quality readings

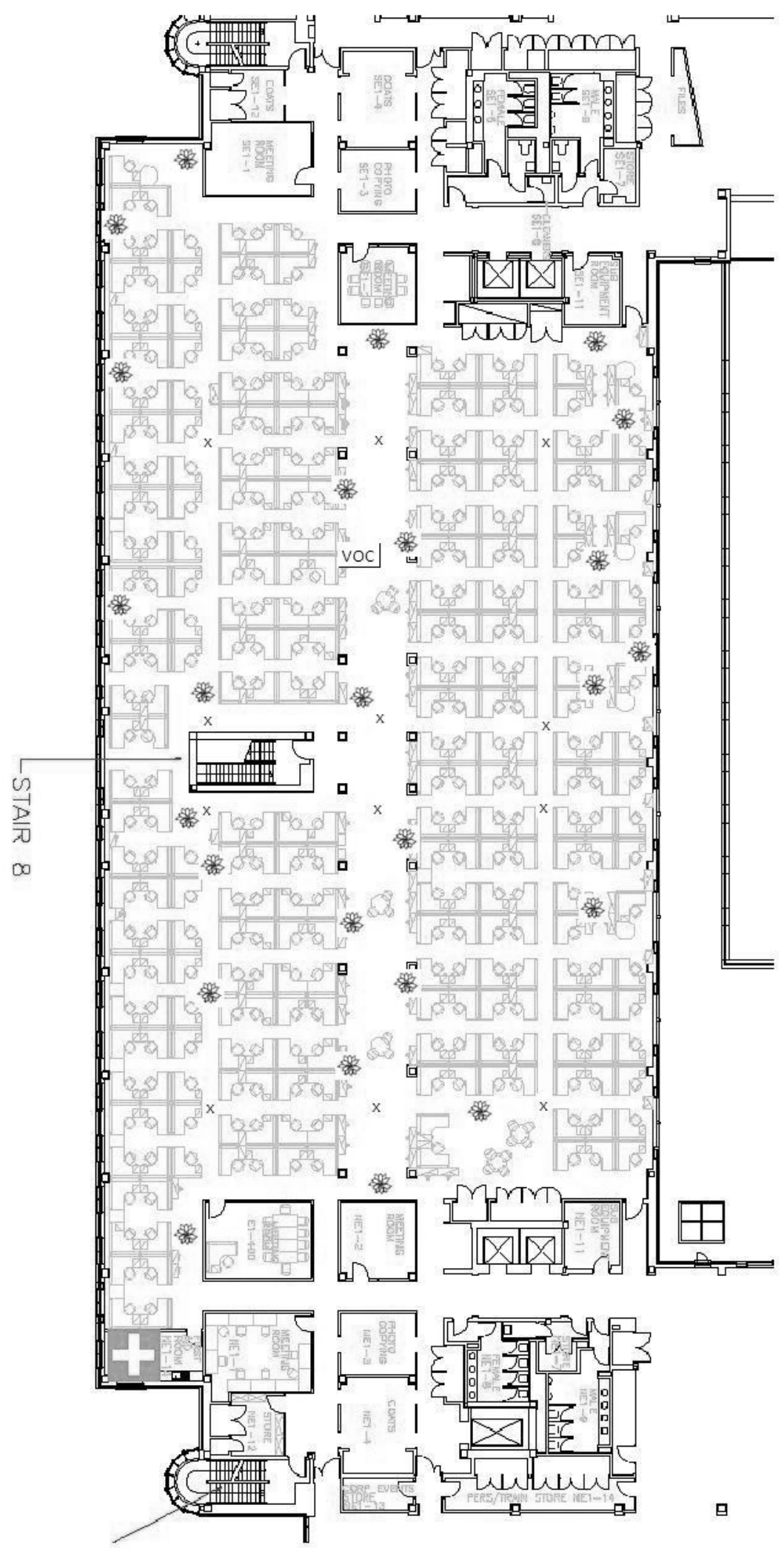

Floor standing plant, $80 \mathrm{~cm}-1.8 \mathrm{~m}$ (Phase 1 and Phase 2) (Not to scale) $\mathrm{x} \quad$ Location of air quality readings

VOC Location of VOC readings 
Figure 2: Daily Average Humidity: East 1 (with plants) and East 2 (control)

Edinburgh - East 1 v East 2: Daily Average Humidity, February - August 2008

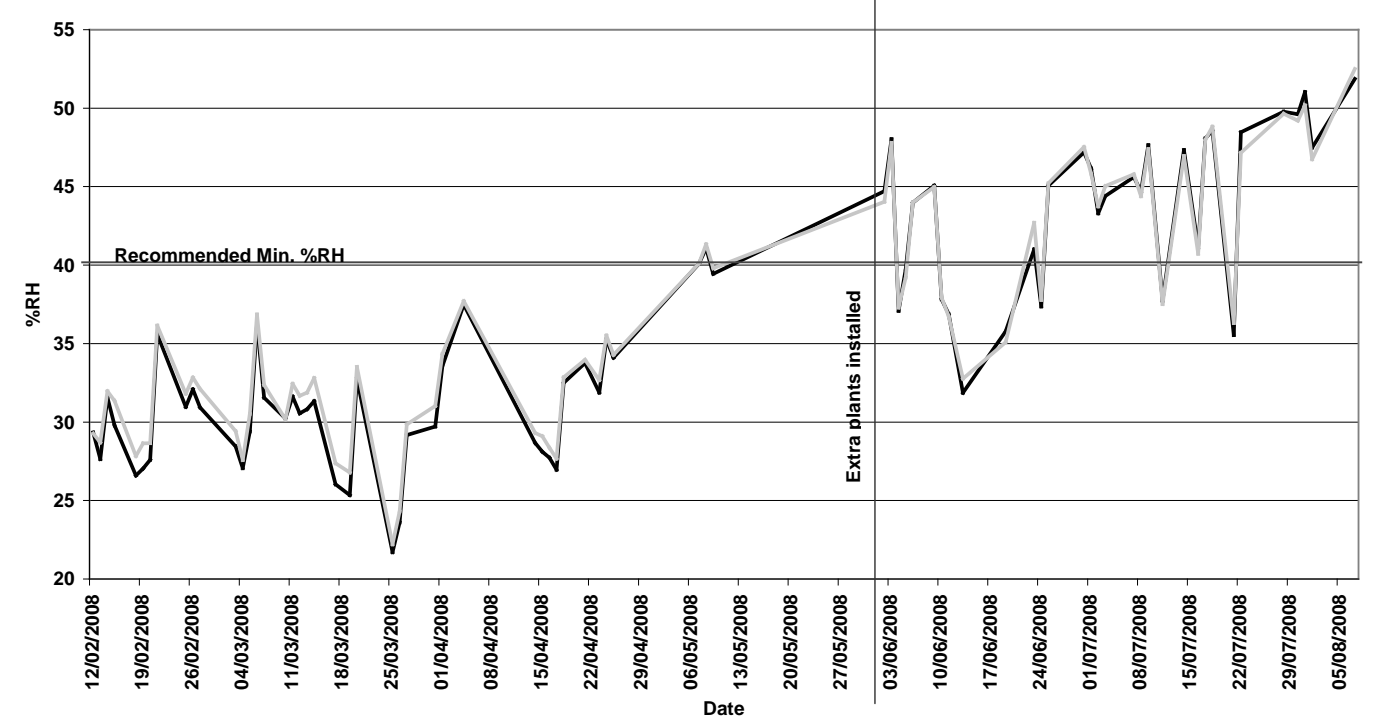

- Humidity — Humidity E1

Accuracy: +/- 2\%RH

Figure 3: Daily Average Humidity - East 1 (with plants)

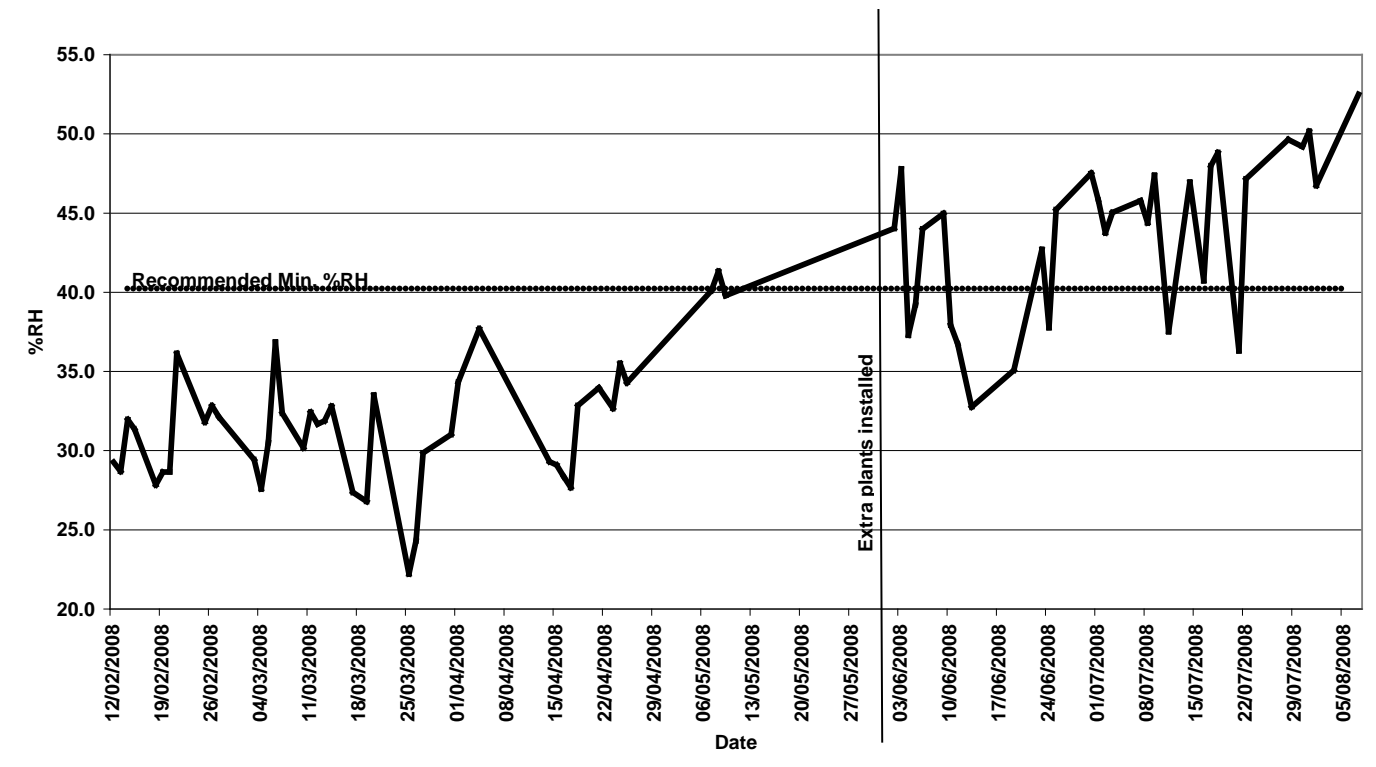

Accuracy: +/- 2\%RH 
Figure 4: Daily Average Humidity - East 1 (minimal planting)

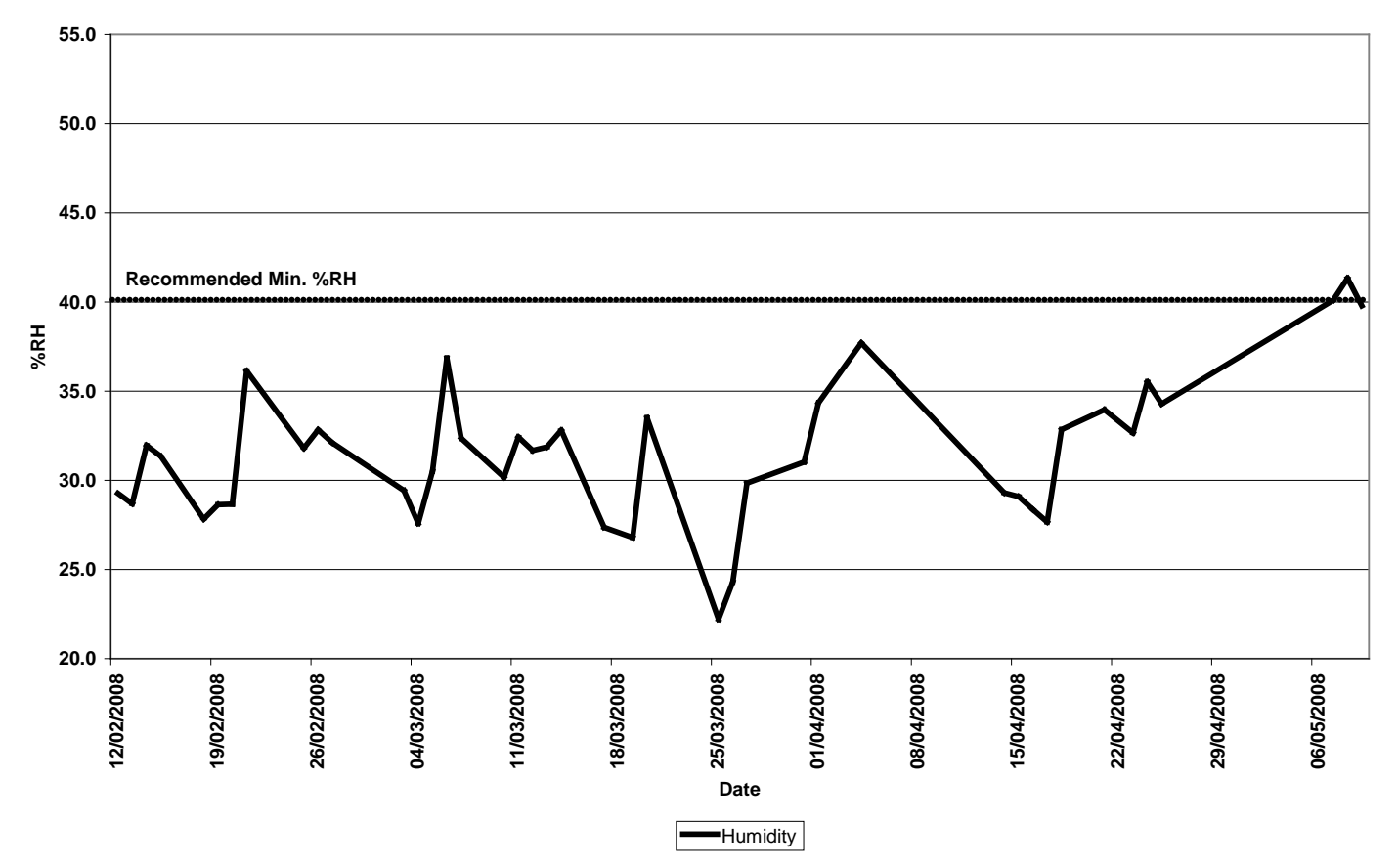

Accuracy: +/- 2\%RH

Figure 5: Daily Average Humidity - East 1 (additional plants)

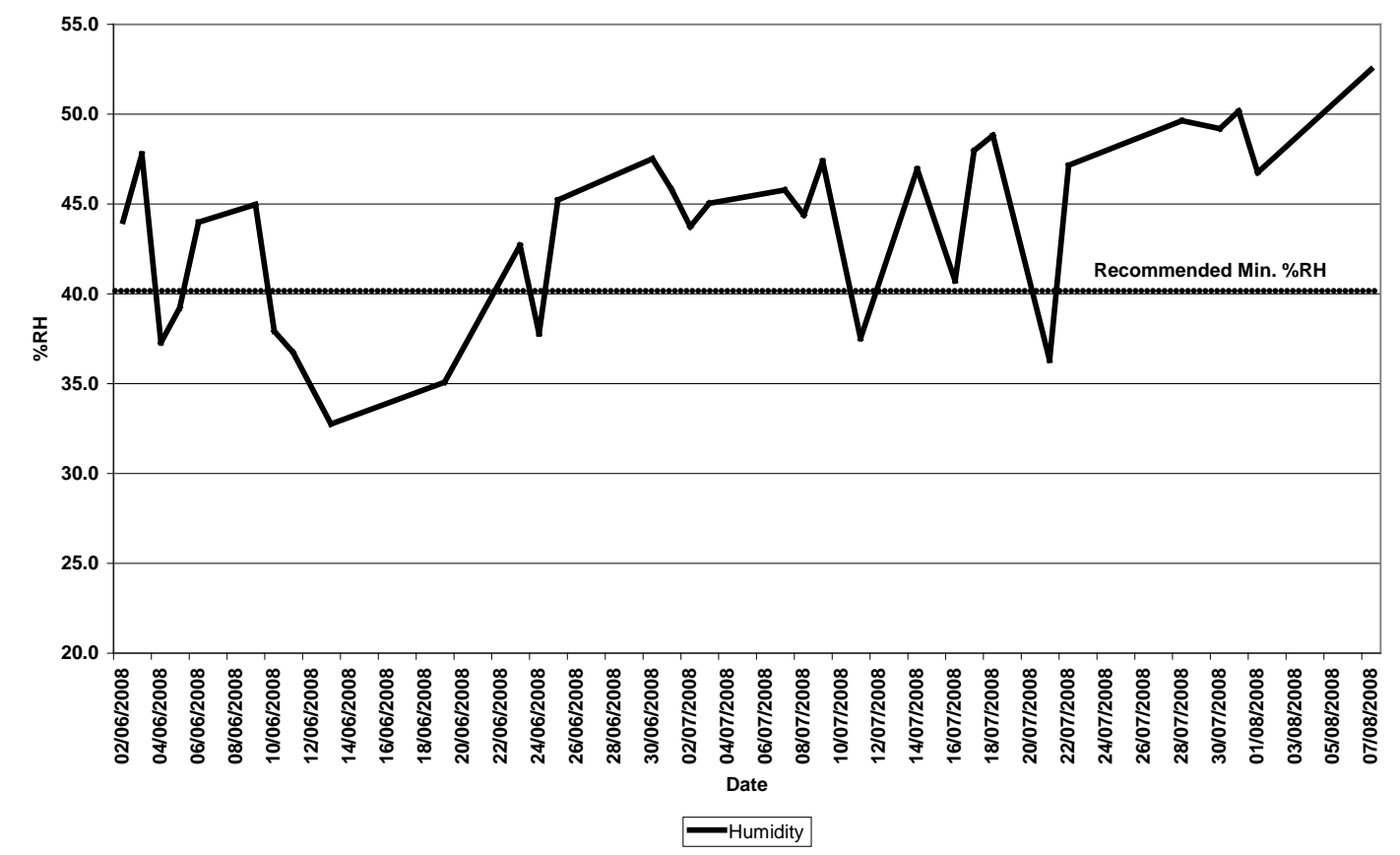

Accuracy: +/- 2\%RH 
Figure 6: Daily Average Carbon Dioxide: East 1 (with plants) and East 2 (control)

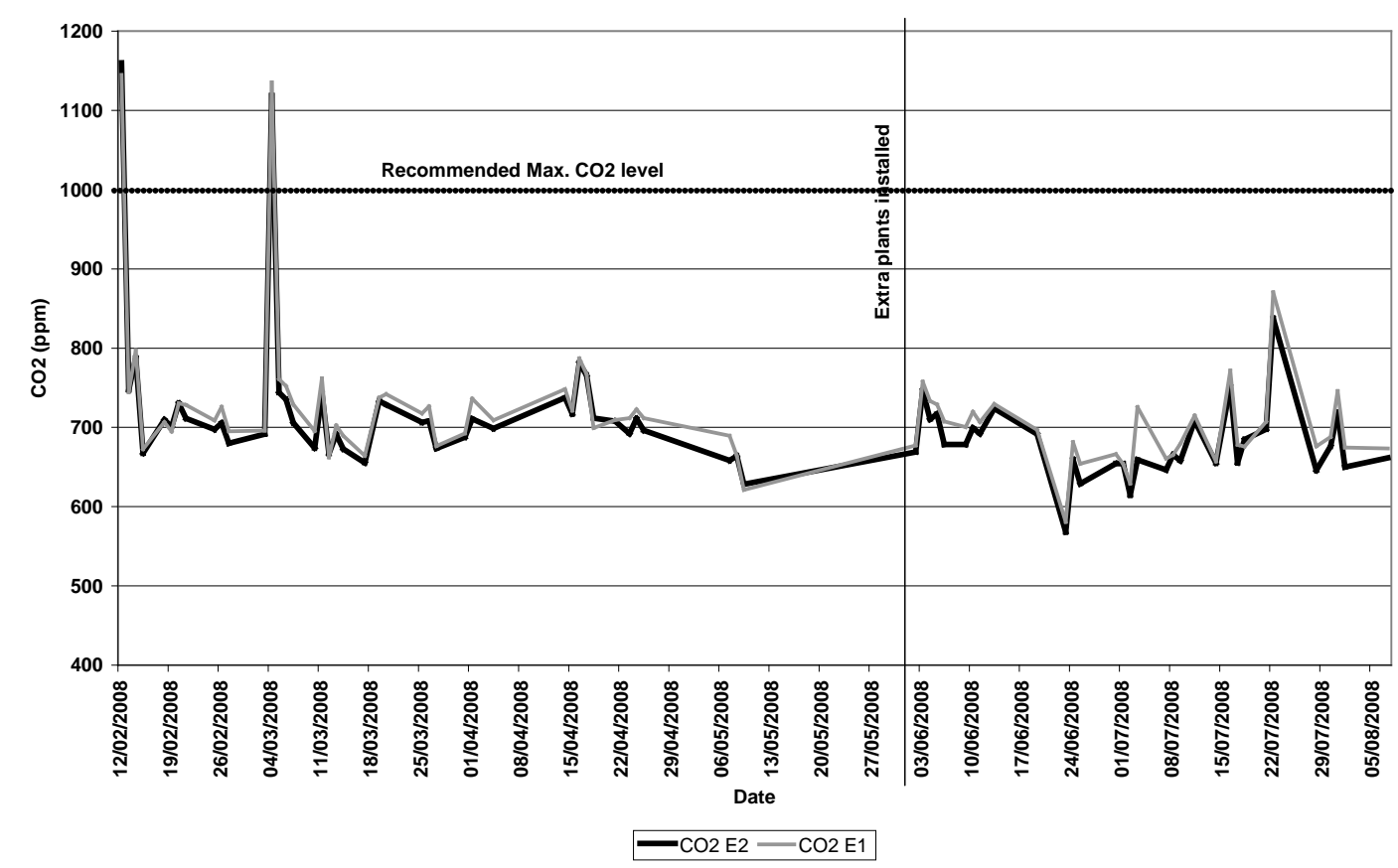

Accuracy: +/- 3\%

Figure 7: Daily Average Carbon Dioxide: East 1 - Minimal Planting

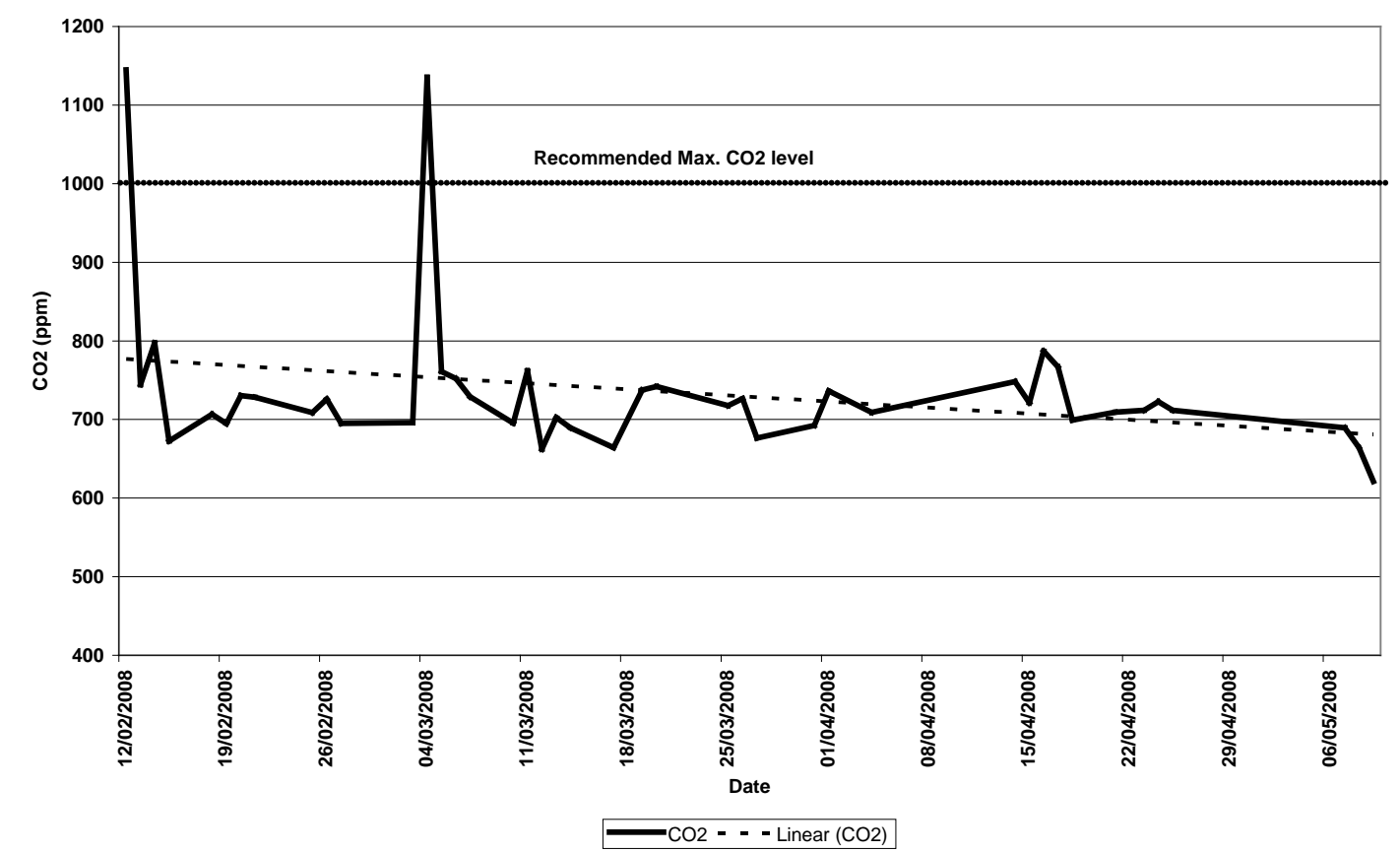

Accuracy: $+/-3 \%$ 
Figure 8: Daily Average Carbon Dioxide: East 1 - Additional Planting

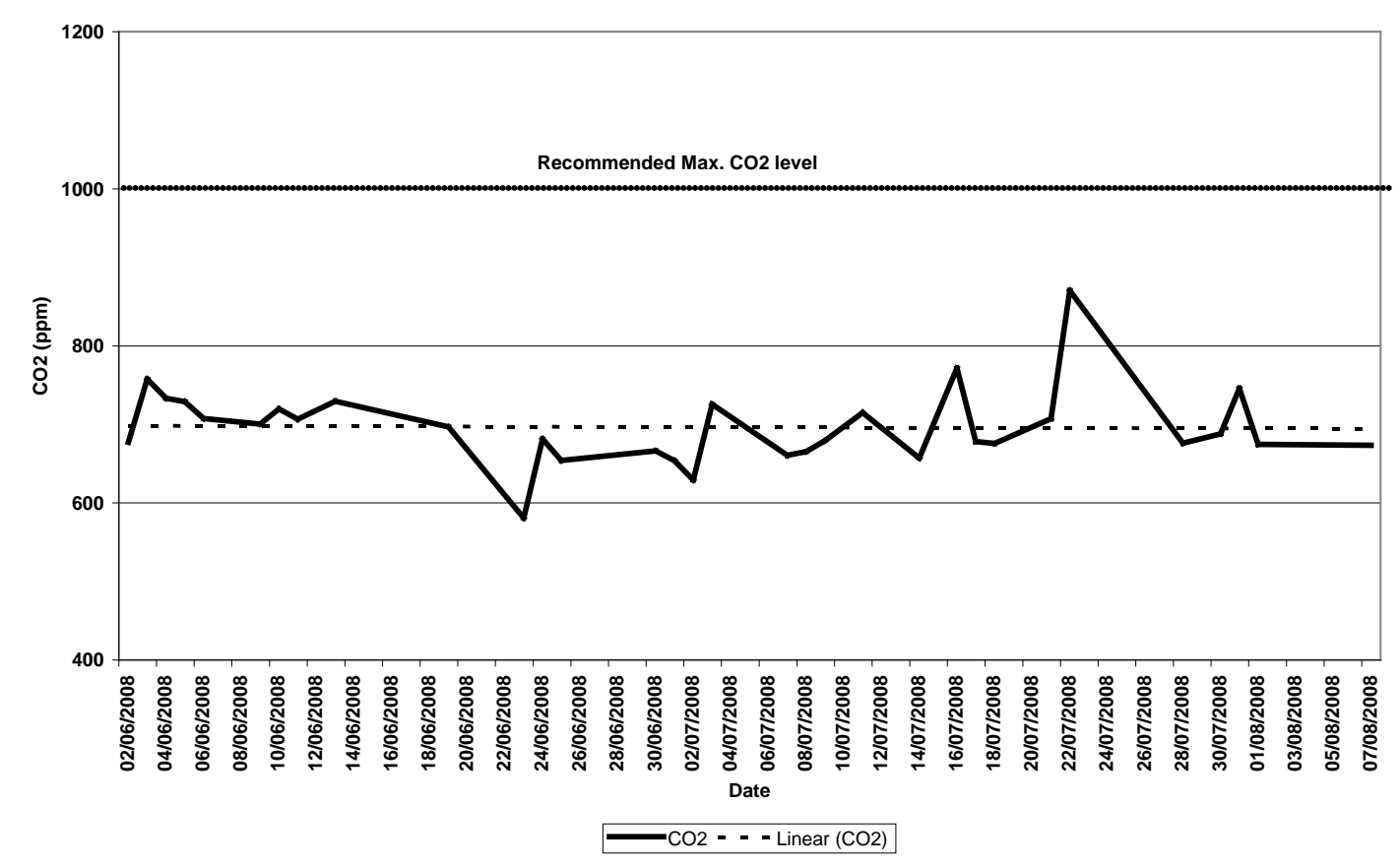

Accuracy: $+/-3 \%$

Figure 9: Daily Average Carbon Monoxide: East 1 (with plants) and East 2 (control)

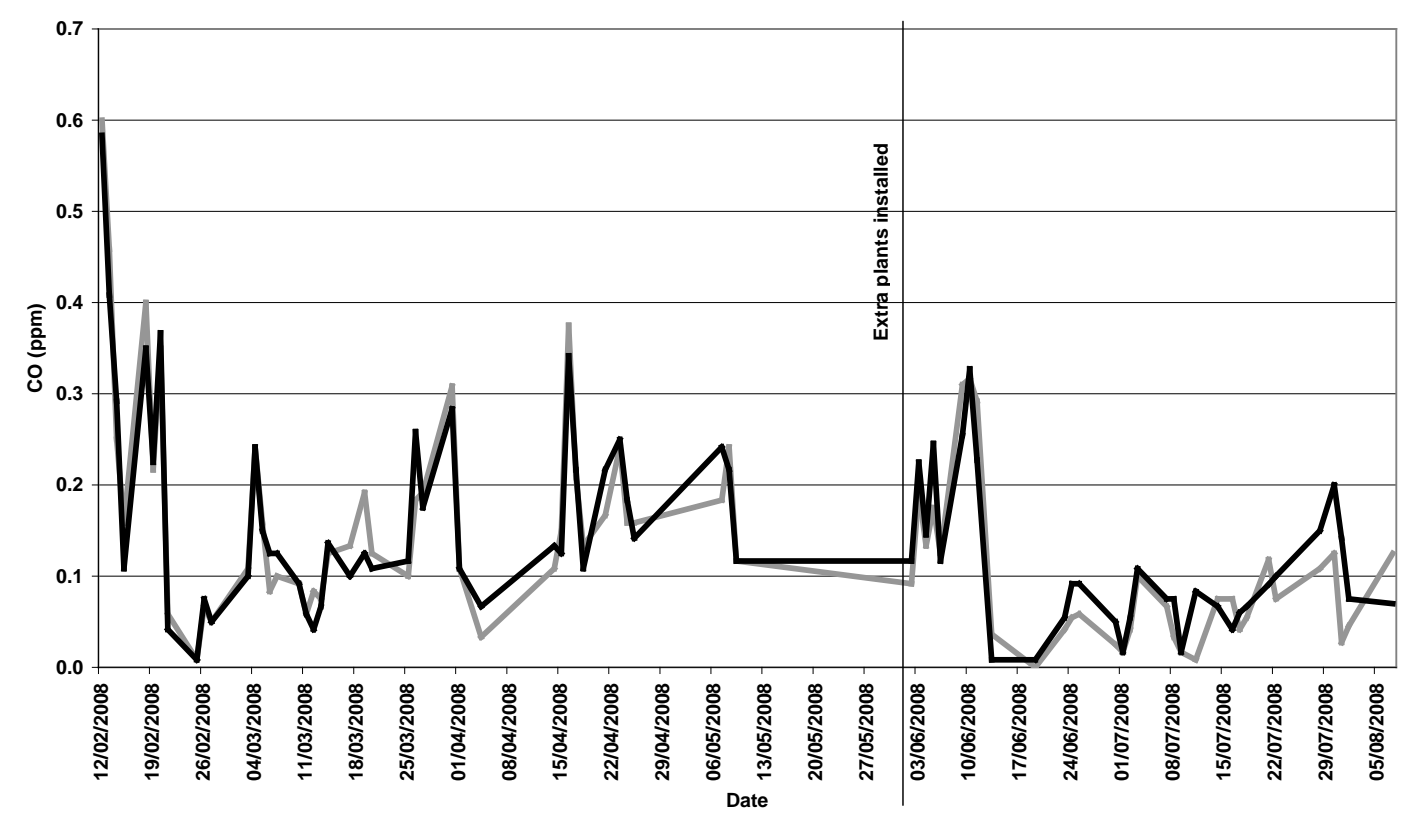

$-\mathrm{COE} 2-\mathrm{COE} 1$

Accuracy: $+/-3 \%$ 
Figure 10: Daily VOC Levels: East 1 (with plants) and East 2 (control)

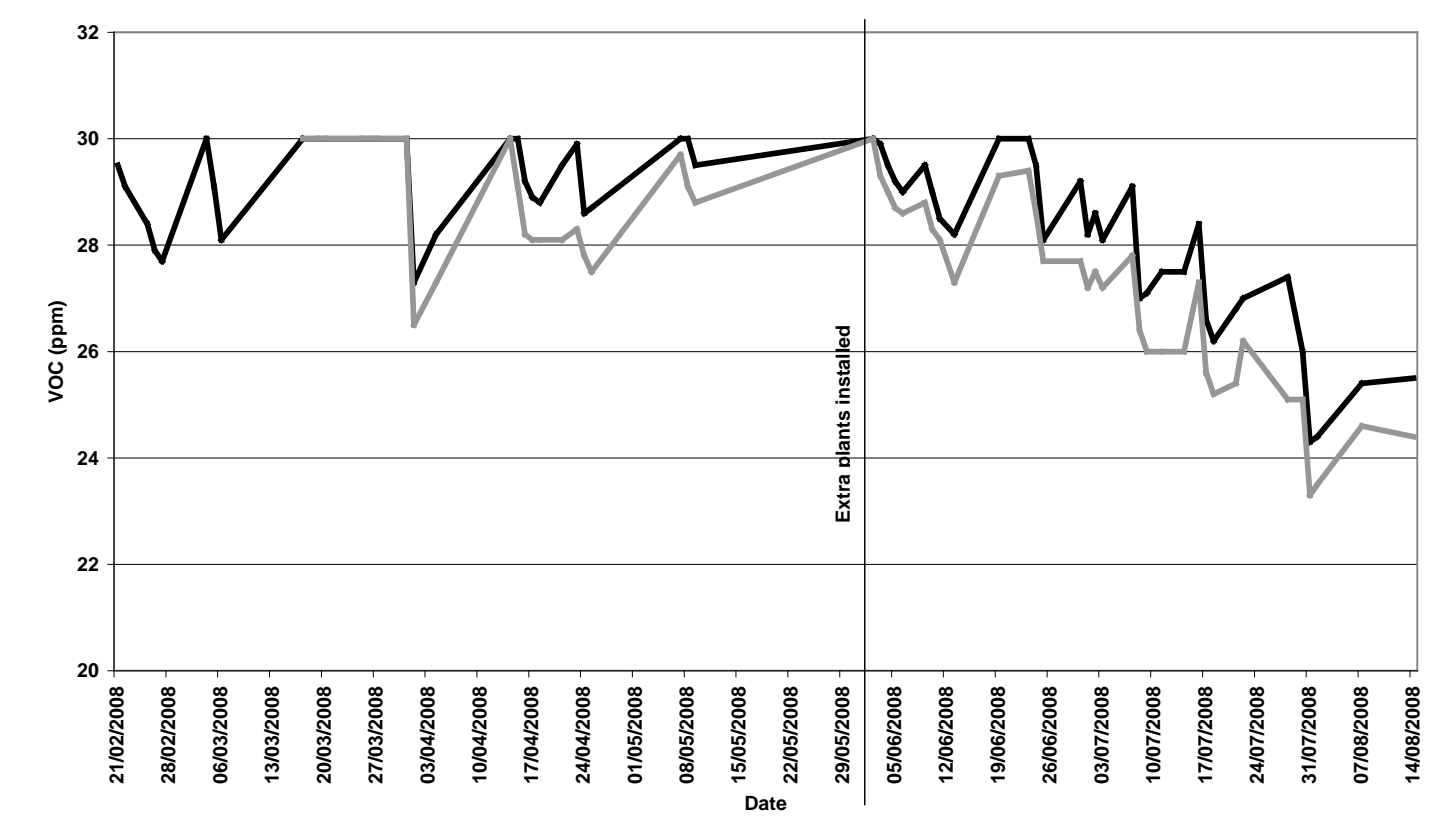

Accuracy: $+/-2 \%$

Figure 11: Daily VOC Levels: East 1 (with plants)

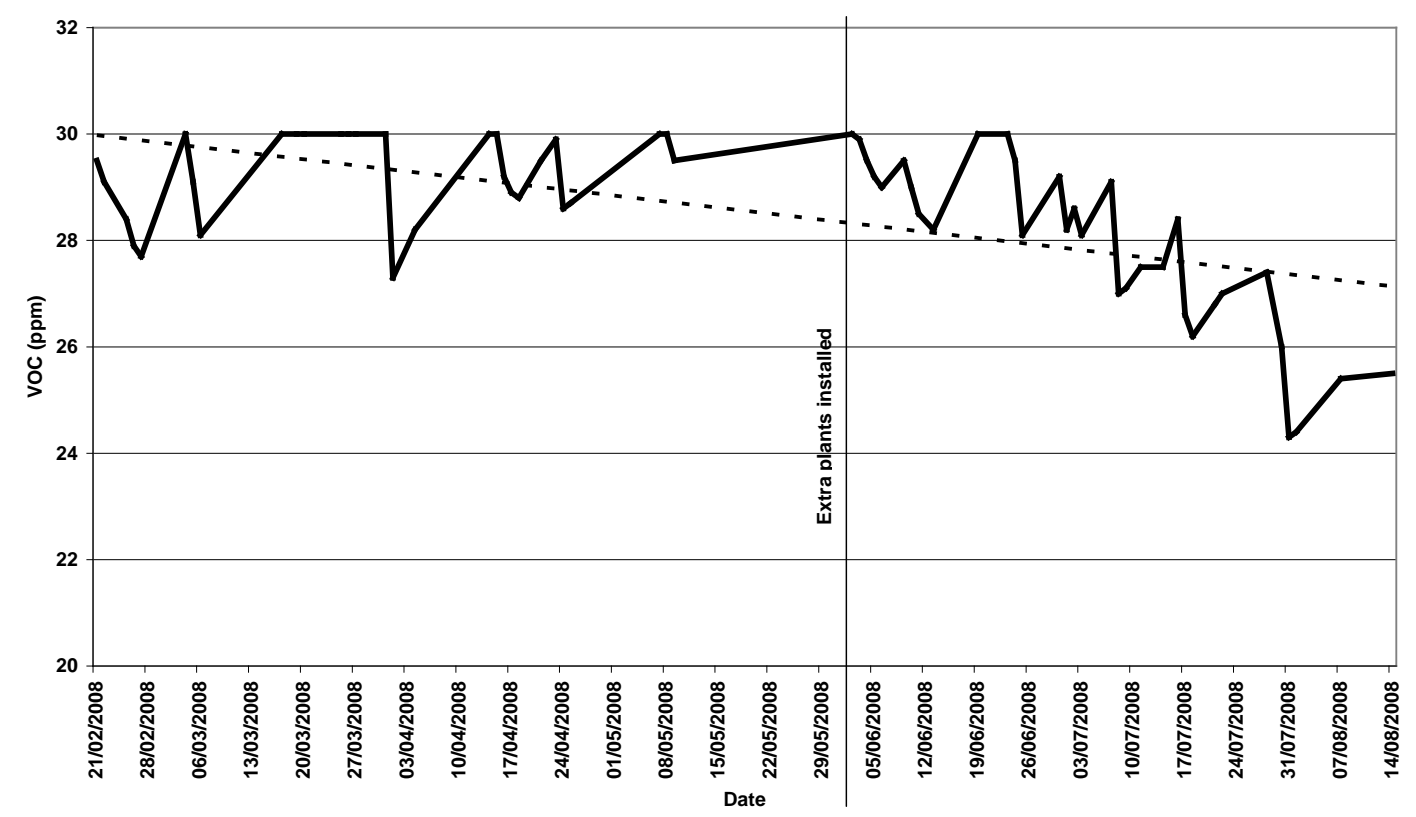

Accuracy: $+/-2 \%$ 